\title{
Björn Onken. "Das antike Perserreich zur Zeit der Achaimeniden in deutschen und italienischen Schulbüchern im 20./21. Jahrhundert"
}

Reinhardt Pirngruber

\section{(2) OpenEdition \\ 1 Journals}

\section{Electronic version}

URL: https://journals.openedition.org/abstractairanica/53522

DOI: 10.4000/abstractairanica.53522

ISSN: 1961-960X

Publisher:

CNRS (UMR 7528 Mondes iraniens et indiens), Éditions de l'IFRI

\section{Electronic reference}

Reinhardt Pirngruber, "Björn Onken. "Das antike Perserreich zur Zeit der Achaimeniden in deutschen und italienischen Schulbüchern im 20./21. Jahrhundert"', Abstracta Iranica [Online], Volume 42-43| 2021, document 62, Online since 30 December 2021, connection on 27 December 2022. URL: http:// journals.openedition.org/abstractairanica/53522 ; DOI: https://doi.org/10.4000/abstractairanica. 53522

This text was automatically generated on 27 December 2022 .

All rights reserved 


\title{
Björn Onken. "Das antike Perserreich zur Zeit der Achaimeniden in deutschen und italienischen Schulbüchern im 20./21. Jahrhundert"
}

\author{
Reinhardt Pirngruber
}

\section{REFERENCES}

Björn Onken. "Das antike Perserreich zur Zeit der Achaimeniden in deutschen und italienischen Schulbüchern im 20./21. Jahrhundert" in R. Rollinger, K. Ruffing, L. Thomas (eds.). Das Weltreich der Perser. Rezeption - Aneignung - Verargumentierung. Wiesbaden: Harrassowitz Verlag, 2019, p. 345-378.

B. Onken looks at the representation of the Achaemenid Empire in history textbooks for German schoolchildren, including a comparison with Italy. While Persia's cultural achievements are generally appreciated, its political system is often contrasted negatively with Greek democracy. The author concludes that the observed trends towards a rather schematic (and negative) depiction of Persia is primarily owed to decreasing time dedicated to antiquity in general and the contexts in which the empire first and foremost occurs, namely the Persian Wars and Alexander's conquest. 


\section{AUTHORS}

\section{REINHARDT PIRNGRUBER}

Institut für Orientalistik, Wien 